\title{
Diversity of butterflies (Lepidoptera) across rainforest transformation systems in Jambi, Sumatra, Indonesia
}

\author{
RAWATI PANJAITAN ${ }^{1}$, JOCHEN DRESCHER ${ }^{2}$, DAMAYANTI BUCHORI ${ }^{3}$, DJUNIJANTI PEGGIE ${ }^{4}$, \\ IDHAM SAKTI HARAHAP ${ }^{3}$, STEFAN SCHEU ${ }^{2}$, PURNAMA HIDAYAT ${ }^{3, \bullet}$ \\ ${ }^{1}$ Program of Entomology, School of Graduates, Institut Pertanian Bogor. Jl. Raya Dramaga, IPB Darmaga Campus, Bogor 16680, West Java, Indonesia \\ ${ }^{2}$ JFB Institute of Zoology and Anthropology, University of Göttingen. Untere Karspüle 2, 37073 Göttingen, Germany \\ ${ }^{3}$ Department of Plant Protection, Faculty of Agriculture, Institut Pertanian Bogor. Jl. Meranti, IPB Darmaga Campus, Bogor 16680, West Java, Indonesia. \\ Tel.: +62-251-8622642, `email: phidayat@apps.ipb.ac.id \\ ${ }^{4}$ Department of Zoology, Research Center for Biology, Indonesian Institute of Sciences. Jl. Raya Jakarta-Bogor Km 46, Cibinong, Bogor 16911, West \\ Java, Indonesia
}

Manuscript received: 6 June 2020. Revision accepted: 10 October 2020.

\begin{abstract}
Panjaitan R, Drescher J, Buchori D, Peggie D, Harahap IS, Scheu S, Hidayat P. 2020. Diversity of butterflies (Lepidoptera) across rainforest transformation systems in Jambi, Sumatra, Indonesia. Biodiversitas 21: 5119-5127. The high rate of land conversion has put pressure on biodiversity, especially in the tropics. The lowlands of Sumatra, for example, are dominated by increasingly extensive areas of oil palm and rubber monoculture plantations, while rainforests are continuously vanishing. The status of many rainforest animal populations, including iconic insect groups such as butterflies, is largely unclear. With a rapid assessment approach, we studied butterflies along land-use gradients from lowland rainforest, via jungle rubber plantations (rubber agroforest system), to monocultures of rubber and oil palm in Jambi Province, Sumatra. Butterflies were caught in a nested replication design at eight research plots at each of the forest, jungle rubber, and rubber and oil palm locations. Butterfly abundance was the highest in the rainforest (204.3 \pm 82.1 ), slightly lower in the jungle rubber and oil palm areas $(164.9 \pm 61$ and $169.3 \pm 94.9$, respectively), and the lowest in the rubber plantation (108.8 \pm 38.5 ). Similarly, butterfly species richness was the highest in the forest and jungle rubber areas (47.1 \pm 7.7 and $38.8 \pm 7.6$, respectively), followed by the oil palm area (33.3 \pm 9.8$)$, and the lowest in the rubber plantation (26.1 \pm 9.1$)$. Likewise, ShannonWiener diversity was the highest in the rainforest, at an intermediate level in the jungle rubber, and lowest in the oil palm and rubber plantations. Butterfly community composition in the rainforest was very different from that in the other three land-use systems, in which it was similar. Overall, the study demonstrates that rainforest butterfly communities cannot be sustained in agricultural systems, highlighting the importance of rainforests for conserving the diversity of arthropods.
\end{abstract}

Keywords: Sumatra, butterflies, rainforest transformation, EFForTS project

\section{INTRODUCTION}

Large areas of rainforest in Indonesia have been and are still being converted to agricultural systems (Sodhi et al. 2010; Peggie 2014). This process is largely driven by population growth and increased demand for agricultural goods (Morris et al. 2014; Wheeler et al. 2013). In Sumatra, rainforests are mostly converted into monoculture plantations of rubber and oil palm (Drescher et al. 2016), resulting in a profound impact on biodiversity (Teuscher et al. 2016) due to the homogenization of ecosystem structures (Sodhi et al. 2010; Teuscher et al. 2016). Deforestation and forest degradation cause habitat loss, fragmentation, and species isolation (Wheeler et al. 2013). Therefore, comprehensive understanding is needed on how to design and manage landscapes that mitigate biodiversity loss while at the same time maintain the provision of agricultural goods (Gray et al. 2019).

Insects have become one of major biodiversity elements to use in research to understand the diversification of tropical forests that have high biodiversity (Azhar et al. 2011; Alexander and DeVries 2012). Among insects, butterflies are considered as charismatic fauna, making them the most intensively studied arthropod groups in the tropics. Their taxonomical information is relatively well described, in contrast to other insect groups that have a high proportion of unknown species. Butterflies are of significant importance as pollinators (Fukano et al. 2016), and serve as food for birds, bats, and other vertebrates, but their larvae are also recognized as agricultural pests. Due to their ease of visual identification, and the fact that host plants are often known, butterflies have been proposed as a model insect group for the rapid assessment of biodiversity (Kumar 2013; Koneri and Maabuat 2016). The presence of butterflies can also illustrate how butterfly communities and their environmental interactions can be used to assess the functioning of an ecosystem and conservation efforts (Fenner et al. 2018).

Previous studies have shown that land-use change in Southeast Asia is associated with changes in butterfly community composition (Mukherjee et al. 2015), with higher butterfly richness in rainforests than in plantations (Hantson and Baz 2013; Rusman 2015). However, detailed studies based on straightforward experimental design are lacking especially for butterfly research. 
We studied the abundance, species richness, and community composition of butterflies across land-use gradients from lowland rainforest, via jungle rubber plantations (rubber agroforestry systems with extensively cultivated rubber and a high proportion of forest tree species), to monoculture plantations of rubber and oil palm in Jambi Province, Sumatra, Indonesia. Based on previous works in the region (Drescher et al. 2016; Grass et al. 2020), we expected butterfly abundance and species richness to be highest in the lowland rainforest, and lowest in the monoculture plantations of rubber and oil palm, with abundance and richness in the jungle rubber areas being at an intermediate level.

\section{MATERIALS AND METHODS}

\section{Study area and period}

The study was conducted in and around two rainforest reserves, the Bukit Duabelas National Park and Harapan Rainforest in Jambi Province, Sumatra, Indonesia (Figure 1), from July to October 2017. We counted and collected butterflies from four types of land-use: lowland secondary rainforest (henceforth referred to as forest), jungle rubber, and monoculture rubber plantation, and monoculture oil palm plantation. We used the nested, replicated core plot design established by the EFForTS project (Drescher et al.
2016), which consisted of eight 50x50 m plots in each of the four land-use systems. In total, we collected butterflies from 32 plots.

\section{Procedures}

Collection and observation of the butterflies were conducted by direct surveys using a scan sampling method. Butterflies were collected using sweep netting on three parallel transects per core plot, with two transects located on the outer borders of the core plots, and the third located through their center. Catching butterflies used insect nets in the plot for two days per plot. Observations were conducted in the morning (8:00-11:00 am) and afternoon (13:00-16:00 $\mathrm{pm})$. All the butterflies were released after identification in the evening of the sampling day, with the exception of up to two individuals that were dried/mounted and five individuals that were preserved in $99 \%$ ethanol per species for the purpose of species identification and further analysis. Identification and preservation of the specimens were carried out at the Insect Biosystematic Laboratory, at the Department of Plant Protection and the Entomology Laboratory, Zoology Centre, Biology Research Center LIPI, Cibinong. Identification was based on the procedures of D'Abrera (1990) and Seki et al. (1991). A visual field guide of all the butterfly species encountered is available at https://www.uni-goettingen.de/de/handbooks+ and+guides /605977.html.

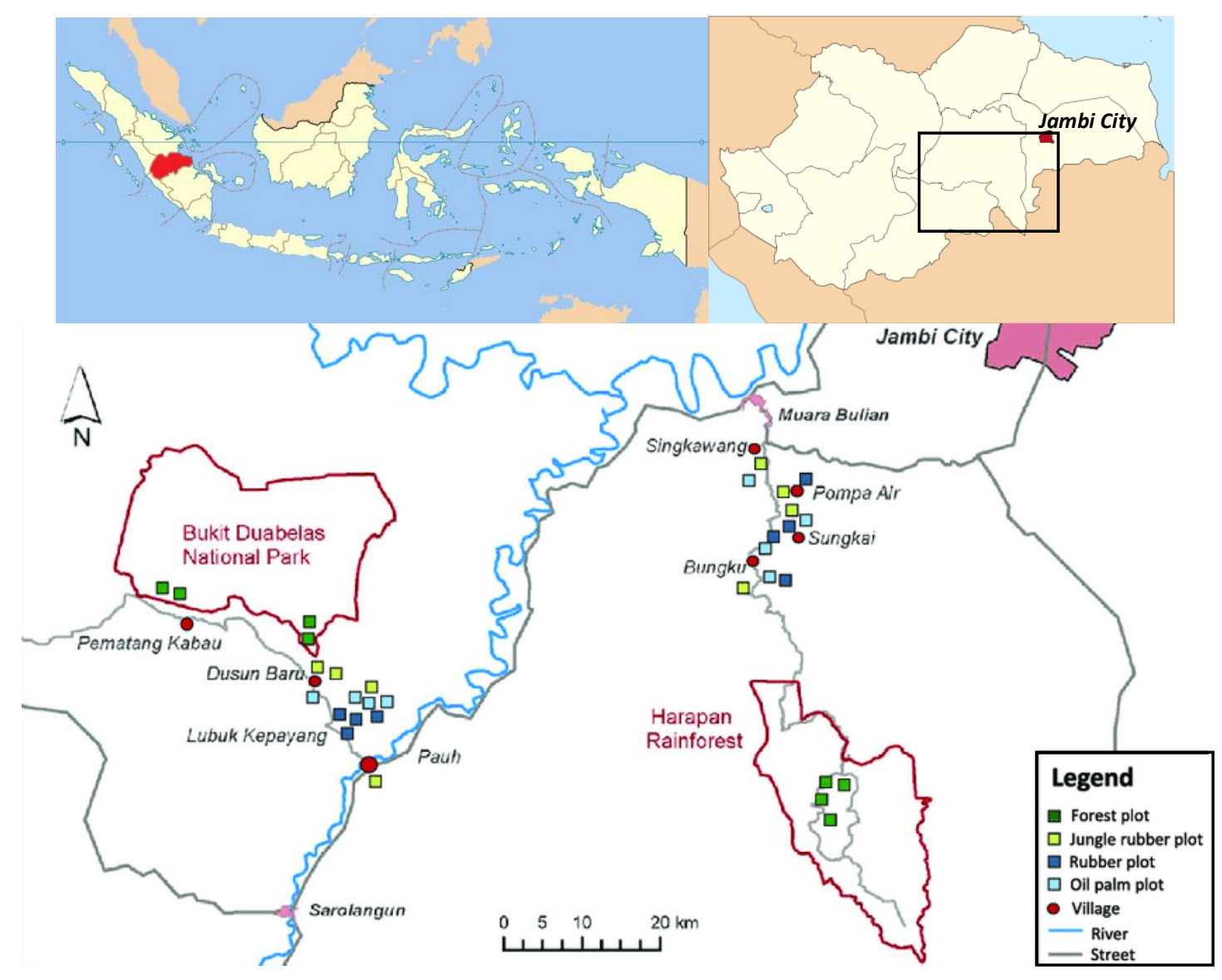

Figure 1. Map of research locations in the Bukit Duabelas National Park and Harapan Rainforest, Jambi, Indonesia (Drescher et al. 2016) 


\section{Data analysis}

We first compared butterfly abundance in the four landuse systems using Waller-Duncan analysis. Butterfly diversity is expressed as the number of species, and additionally calculated as the Shannon-Wiener diversity index $\left(\mathrm{H}^{\prime}\right)$ and Simpson index (D). We tested for differences between species richness among the four landuse systems using Waller-Duncan analysis. Non-metric multidimensional scaling (NMDS) based on Bray Curtis distances was employed to visualize the community composition of butterflies in each land-use system. We then tested for statistical differences in community composition among the land-use systems by Analysis of Similarity (ANOSIM). All of the above were calculated using the vegan package in R 3.0.2 (Hothorn and Everitt 2009). A cumulative analysis of species overlap among the land-use systems was prepared as a Venn diagram, as can be seen at https://bioinfogp.cnb.csic.es/tools/venny/.

\section{RESULTS AND DISCUSSION}

\section{Diversity of butterflies in the four land-use systems}

A total of 5177 individuals consisting of 187 species from 19 sub-families and five families (Lycaenidae, Nymphalidae, Papilionidae, Pieridae, and Riodinidae) were recorded. The butterfly species found were the most from the Nymphalidae family compared to other families. Research conducted by other studies in Sumatra also found the Nymphalidae family to be the most dominant family (Estalita and Basukriadi 2012; Chahyadi and Bibas 2016). Butterfly species richness was the highest in the forest and jungle rubber locations $\left(S_{\mathrm{F}}=47.1 \pm 7.7\right.$ and $\left.S_{J}=38.8 \pm 7.6\right)$, followed by the oil palm plantations $\left(\mathrm{S}_{\mathrm{O}}=33.3 \pm 9.8\right)$, and lowest in the rubber plantations $\left(S_{R}=26.1 \pm 9.1\right)$. Species richness also varied significantly according to land-use $(\mathrm{F}=$ 8.54, $\mathrm{P}=0.0003$; Figure 2). Abundance was the highest in the rainforest $(204.3 \pm 82.1)$, the lowest in the rubber plantations (169.3 \pm 94.9$)$, and intermediate in the jungle rubber $(164.9 \pm 6)$ and oil palm plantations $(108.8 \pm 38.5)(\mathrm{F}$ $=2.38, \mathrm{P}=0.0905$; Figure 3). It declined in an almost linear way from rainforest, to jungle rubber, oil palm, and rubber plantations. Similarly, the Shannon-Wiener diversity $\left(\mathrm{H}^{\prime}\right)$ of butterfly species was the highest in the rainforests (4.1), slightly lower in the jungle rubber areas (3.9), and distinctly lower in the rubber (3.5) and oil palm plantations (3.4). The Simpson index followed a very similar pattern, but was equally high in the rainforest $(0.97)$ and jungle rubber (0.96) areas.

The high diversity of butterflies in the rainforests is presumably related to their more heterogeneous structure, but also to the higher plant diversity compared to the other land-use systems (Rembold et al. 2017; Brown and Crone 2016). Harmonis and Saud (2017) also showed that butterfly diversity is higher in forests compared to degraded habitats. Generally, the presence of butterflies is highly correlated with the presence of host plants, which are used by the imago to lay eggs and on which caterpillars can then feed. Therefore, the transformation of plant communities will affect the biodiversity of butterflies (Nidup et al. 2014). Surprisingly, however, the decline in butterfly species with the transformation of rainforests into plantations was much less steep than that of plant species. At our study sites, the total number of plant species in the rainforests, and jungle rubber, oil palm, and rubber plantations were 963, 652, 219, and 230, respectively (Rembold et al. 2017); that is, compared to the rainforests there were only around $23 \%$ of the number of plant species in the oil palm and rubber plantations. This presumably reflects the fact that butterfly caterpillars often feed on a number of plant species, typically of the same genus or family of plants (Fukano et al. 2016). Furthermore, however, in particular, in the oil palm and rubber plantations, butterfly species richness may benefit from immigration from adjacent habitats. In fact, the landscape configurations that connect forest patches maintain more diverse butterfly communities than those with only monoculture plantations (Gilbert 2012).

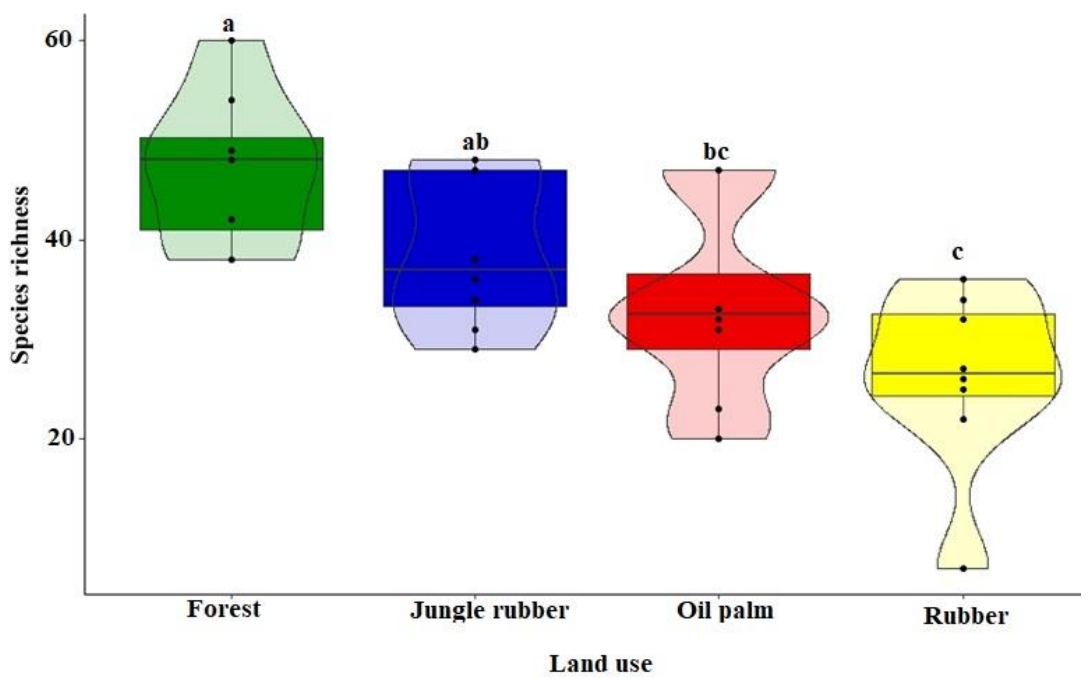

Figure 2. Species richness of butterflies in the four land-use systems studied, using the Waller-Duncan test with F: 8.54 and a P-value of 0.0003. Note: the difference in letters indicates a significant difference between land-uses; The box shape describes the values of Q1, Q2 (mean), and Q3; violin shape (middle box accompanied by dots) shows the distribution of data on each land-use 


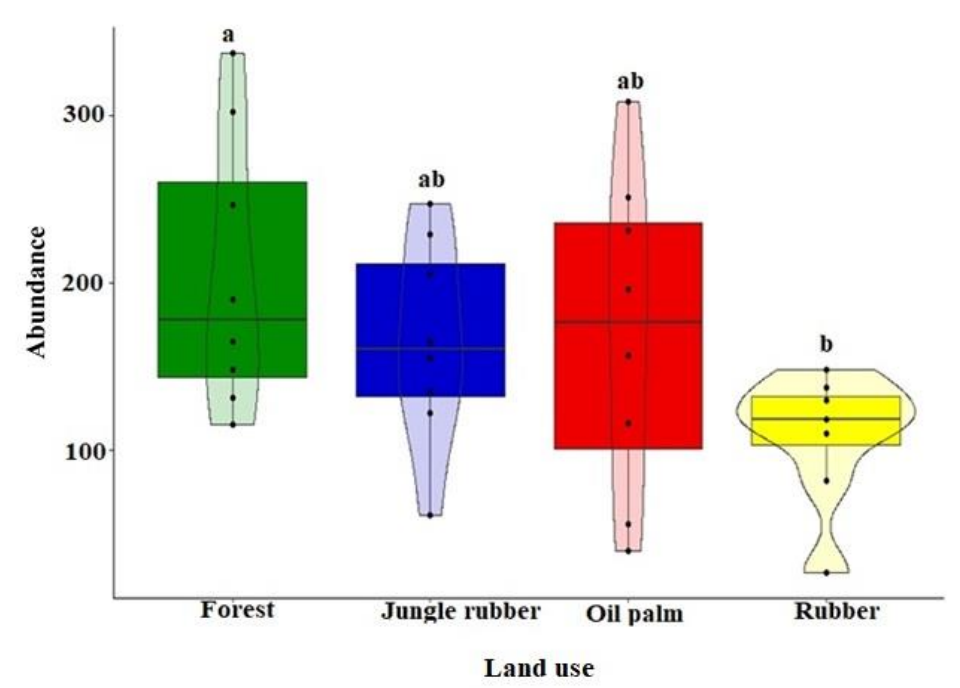

Figure 3. Abundance of butterflies in the rainforests, and jungle rubber, rubber, and oil palm plantations; means \pm SD. Note: the difference in letters shows significant differences between land-uses. The box shape describes the values of Q1, Q2 (mean), and Q3; violin shape (middle box accompanied by dots) shows the distribution of data on each land-use

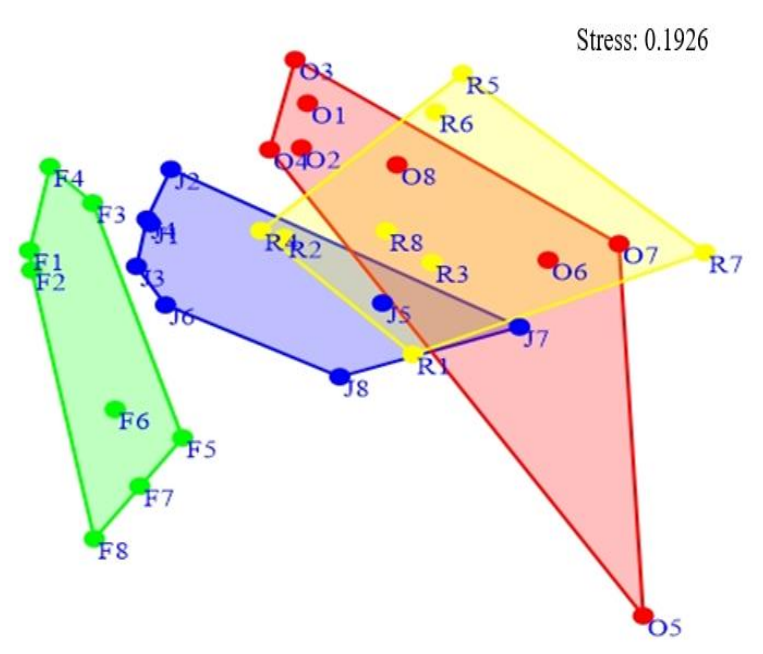

Figure 4. NMDS of butterfly community composition in the rainforest $(\mathrm{F}$, green), jungle rubber ( $\mathrm{J}$, blue), rubber ( $\mathrm{R}$, yellow), and oil palm plantations $(\mathrm{O}$, red), based on Bray Curtis distances

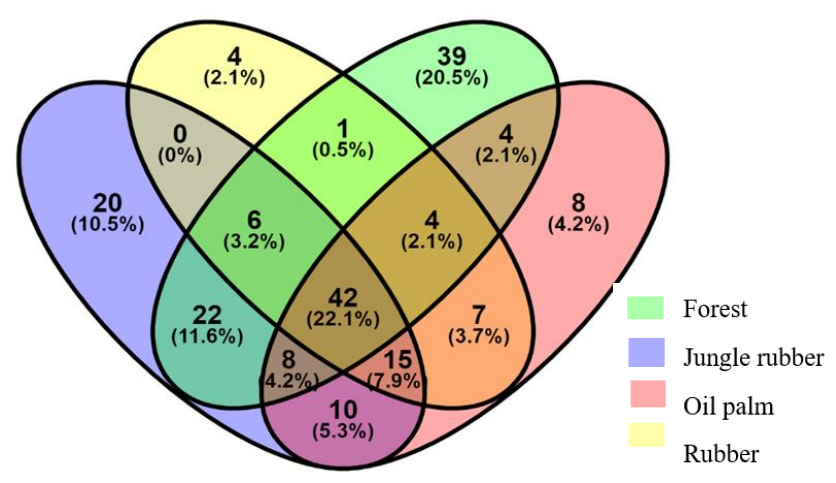

Figure 5. Similarity in butterfly species composition in the four types of land-use
NMDS separated the rainforest butterfly communities from those of each of the other land-use systems. Furthermore, jungle rubber communities were separated from those of the oil palm and rubber plantations, but the latter overlapped widely (Figure 4). It is likely that the differences reflect the differences in habitat structure and plant community composition in the four land-use systems and are related to food, i.e. host plants, but also to the abiotic variables related to canopy openness. In fact, microclimatic conditions in oil palm and rubber plantations differ markedly from those in rainforest and jungle rubber areas (Meijide et al. 2018). The similarity in butterfly species composition between land-uses is based on the Bray Curtis index (stress value: 0.1924; Anosim $\mathrm{R}_{1}$ : 0.66; $R_{2}$ : 0.16), which is considered more relevant to illustrate the relationship with the characteristics of each land-use compared to simply the number of butterfly species. Diverse vegetation will enable butterflies to vary. The difference in the composition of vegetation in different land-uses is thought to be the cause of differences in the composition of butterflies found there. In oil palm and rubber plantations, vegetation is more homogeneous compared to that in forest and jungle rubber locations. Transforming forests into monoculture plantations has a negative impact on species diversity in all taxons (Grass et al. 2020). The forest transformation that has occurred in Sumatra has negatively affected species richness (Barnes et al. 2014), and it has been proven in this study that the diversity of butterflies was lower compared to that in the oil palm and rubber plantations.

The Venn diagrams illustrate that there were similarities among the land-use systems, but also there were unique species in each of these (Figure 5; Table 1). 
Table 1. List of butterfly species found in four land-use systems in the studied area

\begin{tabular}{|c|c|c|c|c|}
\hline Family/Subfamily/Species & Forest & Jungle rubber & Oil palm & Rubber \\
\hline \multicolumn{5}{|l|}{ Lycaenidae } \\
\hline \multicolumn{5}{|l|}{ Curetinae } \\
\hline Curetis tagalica Felder, 1862 & $\sqrt{ }$ & $\sqrt{ }$ & - & - \\
\hline Curetis freda Eliot, 1959 & $\sqrt{ }$ & - & - & - \\
\hline \multicolumn{5}{|l|}{ Miletinae } \\
\hline Allotinus substrigosus Moore, 1884 & $\sqrt{ }$ & $\sqrt{ }$ & - & - \\
\hline Allotinus unicolor Felder \& Felder, 1865 & $\sqrt{ }$ & $\sqrt{ }$ & - & - \\
\hline Logania marmorata Moore, 1884 & - & $\sqrt{ }$ & $\sqrt{ }$ & - \\
\hline Miletus gaetulus de Niceville, 1894 & $\sqrt{ }$ & $\sqrt{ }$ & $\sqrt{ }$ & $\sqrt{ }$ \\
\hline Miletus gopara de Niceville, 1890 & - & $\sqrt{ }$ & - & - \\
\hline Spalgis epius (Westwood, 1851) & - & $\sqrt{ }$ & - & - \\
\hline \multicolumn{5}{|l|}{ Polyommatinae } \\
\hline Acytolepis puspa (Horsfield, 1828) & - & - & $\sqrt{ }$ & - \\
\hline Anthene licaenina (Felder, 1868) & $\sqrt{ }$ & - & - & - \\
\hline Caleta elna (Hewitson, 1876) & $\sqrt{ }$ & - & - & - \\
\hline Discolampa ethion (Westwood, 1851) & - & - & - & $\sqrt{ }$ \\
\hline Euchrysops cnejus (Fabricius, 1798) & - & - & $\sqrt{ }$ & - \\
\hline Everes lacturnus (Godart, [1824]) & $\sqrt{ }$ & - & $\sqrt{ }$ & - \\
\hline Jamides alecto Felder, 1860 & $\sqrt{ }$ & $\sqrt{ }$ & $\sqrt{ }$ & $\sqrt{ }$ \\
\hline Jamides celeno (Cramer, 1775) & $\sqrt{ }$ & $\sqrt{ }$ & $\sqrt{ }$ & $\sqrt{ }$ \\
\hline Jamides talinga Kheil, 1884 & - & $\sqrt{ }$ & - & - \\
\hline Jamides caeruleus Druce, 1873 & - & $\sqrt{ }$ & $\sqrt{ }$ & - \\
\hline Jamides philatus Snellen, 1878 & - & - & $\sqrt{ }$ & - \\
\hline Lycaenopsis haraldus (Fabricius, 1787) & $\sqrt{ }$ & - & - & - \\
\hline Nacaduba kurava (Moore, 1857) & $\sqrt{ }$ & $\sqrt{ }$ & $\sqrt{ }$ & $\sqrt{ }$ \\
\hline Nacaduba calauria (Felder, 1860) & - & $\sqrt{ }$ & - & - \\
\hline Neopithecops zalmora (Butler, 1870) & - & $\sqrt{ }$ & - & - \\
\hline Prosotas gracilis (Röber, 1886) & $\sqrt{ }$ & $\sqrt{ }$ & - & - \\
\hline Zizula hylax (Fabricius, 1775) & - & - & $\sqrt{ }$ & $\sqrt{ }$ \\
\hline \multicolumn{5}{|l|}{ Poritiinae } \\
\hline Poritia sumatrae (Felder \& Felder, 1865) & $\sqrt{ }$ & $\sqrt{ }$ & - & - \\
\hline \multicolumn{5}{|l|}{ Theclinae } \\
\hline Arhopala agesias Hewitson, 1862 & $\sqrt{ }$ & $\sqrt{ }$ & - & $\sqrt{ }$ \\
\hline Arhopala agesilaus Staudinger, 1889 & $\sqrt{ }$ & $\sqrt{ }$ & - & - \\
\hline Arhopala paraganesa (de Niceville, 1882) & $\sqrt{ }$ & $\sqrt{ }$ & - & - \\
\hline Cheritra freja ( Fabricius, 1793) & $\sqrt{ }$ & - & - & - \\
\hline Dacalana vidura (Horsfield, 1828) & $\sqrt{ }$ & - & - & - \\
\hline Deudorix epijarbas (Moore, 1858) & $\sqrt{ }$ & $\sqrt{ }$ & - & - \\
\hline Drupadia niasica (Rober, 1886) & $\sqrt{ }$ & $\sqrt{ }$ & - & - \\
\hline Drupadia ravindra (Horsfield, 1829) & $\sqrt{ }$ & $\sqrt{ }$ & $\sqrt{ }$ & $\sqrt{ }$ \\
\hline Eliotia jalindra (Horsfield, 1829) & $\sqrt{ }$ & - & - & - \\
\hline Eooxylides tharis (Geyer, 1837) & $\sqrt{ }$ & $\sqrt{ }$ & $\sqrt{ }$ & $\sqrt{ }$ \\
\hline Flos fulgida (Hewitson, 1863) & - & $\sqrt{ }$ & - & - \\
\hline Iraota rochana (Horsfield, 1829) & - & - & $\sqrt{ }$ & - \\
\hline Loxura atymnus (Cramer, 1780) & $\sqrt{ }$ & - & - & - \\
\hline Rapala dieneces (Hewitson, 1878) & $\sqrt{ }$ & $\sqrt{ }$ & $\sqrt{ }$ & - \\
\hline Rapala domitia (Hewitson, 1863) & $\sqrt{ }$ & - & - & - \\
\hline Rapala manea (Hewitson, 1863) & $\sqrt{ }$ & $\sqrt{ }$ & $\sqrt{ }$ & - \\
\hline Rapala rhodopis de Nicéville, 1896 & $\sqrt{ }$ & - & - & - \\
\hline Sithon nedymond (Cramer, 1782) & - & $\sqrt{ }$ & $\sqrt{ }$ & $\sqrt{ }$ \\
\hline Spindasis lohita (Horsfield, 1829) & - & $\sqrt{ }$ & - & - \\
\hline Surendra vivarna (Hewitson, 1829) & $\sqrt{ }$ & - & - & $\sqrt{ }$ \\
\hline Thamala marciana (Hewitson, 1863) & $\sqrt{ }$ & - & - & - \\
\hline \multicolumn{5}{|l|}{ Nymphalidae } \\
\hline \multicolumn{5}{|l|}{ Apaturinae } \\
\hline Eulaceura osteria (Westwood, 1850) & $\sqrt{ }$ & $\sqrt{ }$ & - & $\sqrt{ }$ \\
\hline Euripus nyctelius (Doubleday, 1845) & $\sqrt{ }$ & $\sqrt{ }$ & - & - \\
\hline \multicolumn{5}{|l|}{ Biblidinae } \\
\hline Laringa castelnaui (Felder, 1860) & - & $\sqrt{ }$ & - & - \\
\hline Laringa horsfieldi (Boisduval, 1833) & $\sqrt{ }$ & - & - & - \\
\hline \multicolumn{5}{|l|}{ Charaxinae } \\
\hline Agatasa calydonia (Hewitson, 1855) & $\sqrt{ }$ & $\sqrt{ }$ & - & - \\
\hline Charaxes bernardus (Fanricius, 1793) & $\sqrt{ }$ & $\sqrt{ }$ & $\sqrt{ }$ & $\sqrt{ }$ \\
\hline
\end{tabular}


Charaxes durnfordi Distant, 1884

Charaxes (Polyura) hebe (Butler, 1865)

Charaxes solon (Fabricius, 1793)

Prothoe franck (Godart, [1824])

Cyrestinae

Chersonesia rahria (Moore, $\{1858]$ )

Dichorragia nesimachus (Boisduval, 1836)

Danainae

Danaus genutia (Cramer, [1779])

Danaus melanippus (Cramer, [1777])

Euploea algea (Godart, [1819])

Euploea crameri Lucas, 1853

Euploea mulciber (Cramer, [1777])

Euploea phaenareta (Schaller, 1785)

Euploea radamanthus (Fabricius, 1793)

Idea lynceus (Drury, 1773)

Ideopsis gaura (Horsfield, [1829])

Ideopsis juventa (Cramer, [1777])

Ideopsis vulgaris (Butler, 1874)

Parantica aspasia (Fabricius, 1787)

Parantica luzonensis (Felder \& Felder, 1863)

Heliconiinae

Acraea terpsicore (Linnaeus, 1758 )

Cethosia hypsea Doubleday, 1847

Cirrochroa emalea (Guérin-Méneville, 1843)

Cupha erymanthis (Drury, 1773)

Cupha orissa Felder, 1860

Terinos terpander Hewitson, 1862

Vindula erota (Fabricius, 1793)

Limenitidinae

Athyma kanwa (Moore, 1858)

Athyma bravura (Moore, 1858)

Athyma perius (Linnaeus, 1758)

Athyma reta (Moore, 1858)

Bassarona dunya (Doubleday, 1848)

Bassarona teuta (Doubleday, 1848)

Dophla evelina (Stoll, 1790)

Euthalia adonia (Cramer, 1782)

Euthalia agnis Vollenhoven, 1862

Euthalia alpheda Godart, 1823

Euthalia kanda Moore, 1859

Euthalia mahadeva Moore, 1859

Euthalia merta Moore, 1859

Euthalia monina (Fabricus, 1787)

Euthalia whiteheadi Grose-Smith, 1889

Lasippa tiga (Moore, 1858)

Lebadea martha (Fabricius, 1787)

Lexias pardalis Moore, 1878

Moduza procris (Cramer, 1777)

Neptis harita Moore, 1875

Neptis hylas (Linnaeus, 1758 )

Neptis nata Moore, 1857

Pandita sinope Moore, 1858

Pantoporia aurelia Staudinger, 1886

Tanaecia coelebs Corbet, 1941

Tanaecia elone de Niceville, 1893

Tanaecia palguna (Moore, 1857)

Tanaecia pelea (Fabricius, 1787)

Morphinae

Amathusia binghami Fruhstorfer, 1904

Amathusia perakana Honrath, 1888

Amathusia schoenbergi Honrath, 1888

Discophora necho Felder, 1866

Faunis canens Hübner, 1826

Faunis gracilis Butler, 1867

Faunis kirata de Nicéville, 1891

Thaumantis klugius Zinken-Somer, 1831

\begin{tabular}{|c|c|c|c|}
\hline$\sqrt{ }$ & - & - & - \\
\hline$\sqrt{ }$ & - & $\sqrt{ }$ & $\sqrt{ }$ \\
\hline - & $\sqrt{ }$ & - & - \\
\hline$\sqrt{ }$ & $\sqrt{ }$ & - & - \\
\hline$\sqrt{ }$ & $\sqrt{ }$ & - & - \\
\hline$\sqrt{ }$ & - & - & - \\
\hline$\sqrt{ }$ & - & - & - \\
\hline- & $\sqrt{ }$ & $\sqrt{ }$ & $\sqrt{ }$ \\
\hline$\sqrt{ }$ & - & - & - \\
\hline - & $\sqrt{ }$ & $\sqrt{ }$ & $\sqrt{ }$ \\
\hline$\sqrt{ }$ & $\sqrt{ }$ & $\sqrt{ }$ & $\sqrt{ }$ \\
\hline$\sqrt{ }$ & $\sqrt{ }$ & $\sqrt{ }$ & $\sqrt{ }$ \\
\hline$\sqrt{ }$ & - & - & - \\
\hline$\sqrt{ }$ & $\sqrt{ }$ & - & - \\
\hline$\sqrt{ }$ & $\sqrt{ }$ & $\sqrt{ }$ & - \\
\hline$\sqrt{ }$ & $\sqrt{ }$ & $\sqrt{ }$ & $\sqrt{ }$ \\
\hline$\sqrt{ }$ & $\sqrt{ }$ & - & $\sqrt{ }$ \\
\hline$\sqrt{ }$ & $\sqrt{ }$ & $\sqrt{ }$ & $\sqrt{ }$ \\
\hline$\sqrt{ }$ & - & - & - \\
\hline - & $\sqrt{ }$ & $\sqrt{ }$ & $\sqrt{ }$ \\
\hline$\sqrt{ }$ & $\sqrt{ }$ & $\sqrt{ }$ & $\sqrt{ }$ \\
\hline$\sqrt{ }$ & $\sqrt{ }$ & - & - \\
\hline$\sqrt{ }$ & $\sqrt{ }$ & $\sqrt{ }$ & $\sqrt{ }$ \\
\hline$\sqrt{ }$ & - & - & - \\
\hline$\sqrt{ }$ & $\sqrt{ }$ & $\sqrt{ }$ & - \\
\hline$\sqrt{ }$ & $\sqrt{ }$ & $\sqrt{ }$ & - \\
\hline$\sqrt{ }$ & $\sqrt{ }$ & $\sqrt{ }$ & $\sqrt{ }$ \\
\hline$\sqrt{ }$ & $\sqrt{ }$ & - & - \\
\hline$\sqrt{ }$ & - & $\sqrt{ }$ & $\sqrt{ }$ \\
\hline$\sqrt{ }$ & - & - & - \\
\hline$\sqrt{ }$ & - & - & - \\
\hline$\sqrt{ }$ & - & - & - \\
\hline$\sqrt{ }$ & $\sqrt{ }$ & - & $\sqrt{ }$ \\
\hline - & - & $\sqrt{ }$ & $\sqrt{ }$ \\
\hline - & - & $\sqrt{ }$ & - \\
\hline$\sqrt{ }$ & $\sqrt{ }$ & $\sqrt{ }$ & $\sqrt{ }$ \\
\hline - & - & - & $v$ \\
\hline- & $\sqrt{ }$ & $\sqrt{ }$ & $\sqrt{ }$ \\
\hline- & $\sqrt{ }$ & - & - \\
\hline- & $\sqrt{ }$ & $\sqrt{ }$ & $\sqrt{ }$ \\
\hline- & - & $\sqrt{ }$ & - \\
\hline$\sqrt{ }$ & $\sqrt{ }$ & $\sqrt{ }$ & $\sqrt{ }$ \\
\hline$\sqrt{ }$ & $\sqrt{ }$ & - & - \\
\hline$\sqrt{ }$ & $\sqrt{ }$ & $\sqrt{ }$ & $\sqrt{ }$ \\
\hline$\sqrt{ }$ & $\sqrt{ }$ & $\sqrt{ }$ & $\sqrt{ }$ \\
\hline- & - & $\sqrt{ }$ & - \\
\hline$\sqrt{ }$ & $\sqrt{ }$ & $\sqrt{ }$ & $\sqrt{ }$ \\
\hline$\sqrt{ }$ & $\sqrt{ }$ & $\sqrt{ }$ & $\sqrt{ }$ \\
\hline$\sqrt{ }$ & - & $\sqrt{ }$ & $\sqrt{ }$ \\
\hline$\sqrt{ }$ & - & - & - \\
\hline$\sqrt{ }$ & $\sqrt{ }$ & $\sqrt{ }$ & $\sqrt{ }$ \\
\hline$\sqrt{ }$ & $\sqrt{ }$ & $\sqrt{ }$ & $\sqrt{ }$ \\
\hline$\sqrt{ }$ & $\sqrt{ }$ & $\sqrt{ }$ & $\sqrt{ }$ \\
\hline$\sqrt{ }$ & $\sqrt{ }$ & $\sqrt{ }$ & - \\
\hline$\sqrt{ }$ & $\sqrt{ }$ & $\sqrt{ }$ & $\sqrt{ }$ \\
\hline$\sqrt{ }$ & $\sqrt{ }$ & $\sqrt{ }$ & $\sqrt{ }$ \\
\hline$\sqrt{ }$ & - & - & - \\
\hline - & $\sqrt{ }$ & - & - \\
\hline$\sqrt{ }$ & $\sqrt{ }$ & $\sqrt{ }$ & $\sqrt{ }$ \\
\hline$\sqrt{ }$ & - & - & - \\
\hline$\sqrt{ }$ & - & - & - \\
\hline$\sqrt{ }$ & $\sqrt{ }$ & - & \\
\hline
\end{tabular}


Thaumantis noureddin Westwood, 1851 Zeuxidia amethystus Butler, 1865 Zeuxidia doubledayi Westwood, 1851 Nymphalinae

Ariadne ariadne (Linnaeus, 1763)

Doleschallia bisaltide (Cramer, 1779)

Hypolimnas bolina (Linnaeus, 1758)

Junonia almana (Linnaeus, 1758)

Junonia atlites (Linnaeus, 1763)

Junonia hedonia (Linnaeus, 1764)

Junonia orithya (Linnaeus, 1764)

Satyrinae

Coelites epiminthia Westwood, 1850

Coelites euptychioides Felder, 1867

Elymnias hypermnestra (Linnaeus, 1763)

Elymnias nesaea (Linnaeus, 1758)

Elymnias panthera (Fabricius, 1787)

Elymnias penanga (Westwood, 1851)

Erites argentina Butler, 1868

Lethe mekara Moore, 1857

Melanitis leda (Linnaeus, 1758)

Melanitis phedima (Cramer, 1782)

Mycalesis anapita Moore, 1857

Mycalesis dohertyi Elwes, 1891

Mycalesis fusca Felder, 1860

Mycalesis horsfieldi Moore, 1880

Mycalesis janardana Moore, 1857

Mycalesis maianeas Hewitson, 1864

Mycalesis mineus (Linnaeus, 1758)

Mycalesis mnasicles Hewitson, 1864

Mycalesis marginata Moore, 1881

Mycalesis orseis Hewitson, 1864

Mycalesis oroatis Hewitson, 1864

Mycalesis perseus (Fabricius, 1775)

Neorina lowii (Doubleday, 1849)

Orsotriaena medus (Fabricius, 1775)

Ragadia crisilda de Nicéville, 1890

Ragadia makuta Fruhstorfer, 1911

Ypthima nebulosa Aoki \&Uemura, 1892

Ypthima philomela (Linnaeus, 1763)

Ypthima horsfieldii Moore, 1884

\section{Papilionidae}

Papilioninae

Atrophaneura priapus (Boisduval, 1836)

Graphium agamemnon (Linnaeus, 1758 )

Graphium (Pathysa) antiphates (Cramer, 1775)

Graphium eurypylus (Linnaeus, 1758 )

Graphium ramaceus Westwood, 1872

Graphium sarpedon (Linnaeus, 1758)

Pachliopta antiphus (Fabricius, 1793)

Papilio demoleus Linnaeus, 1758

Papilio demolion Cramer, [1776]

Papilio helenus Linnaeus, 1758

Papilio iswaroides Fruhstorfer, 1898

Papilio memnon Linnaeus, 1758

Papilio nephelus Boisduval, 1836

Papilio polytes Linnaeus, 1758

Trogonoptera brookiana (Wallace, 1855)

Troides amphrysus (Cramer, [1779])

\section{Pieridae}

Coliadinae

Catopsilia pomona (Fabricius, 1775)

Catopsilia scylla (Linnaeus, 1763 )

Eurema alitha (Felder \& Felder, 1862)

Eurema hecabe (Linnaeus, 1758 )

Eurema simulatrix Staudinger, 1891

Gandaca harina (Horsfield, 1829) 


\author{
Pierinae \\ Appias olferna (Swinhoe, 1890) \\ Appias pandione Geyer, 1832 \\ Leptosia nina (Fabricius, 1793) \\ Riodinidae \\ Nemeobiinae \\ Abisara echerius (Stoll, 1790) \\ Abisara savitri (Felder \& Felder, 1860) \\ Paralaxita orphana (Boisduval, 1836) \\ Taxila haquinus (Fabricius, 1793) \\ Zemeros emesoides Felder \& Felder, 1860 \\ Zemeros flegyas (Cramer, 1780)
}

Note: $\sqrt{\text { : Present; -: Absent }}$

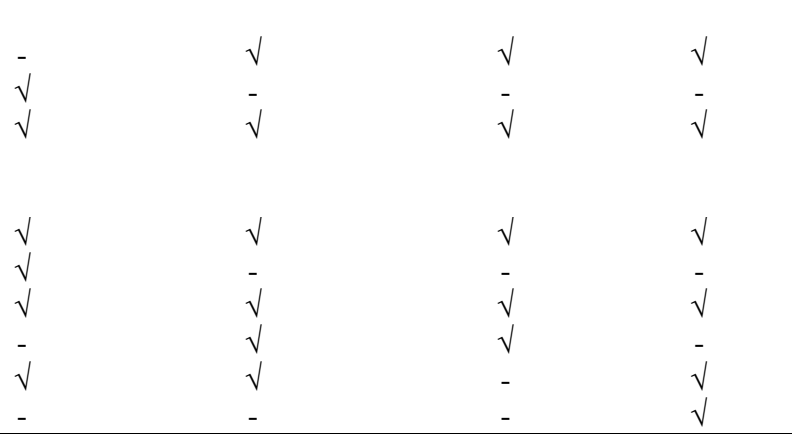

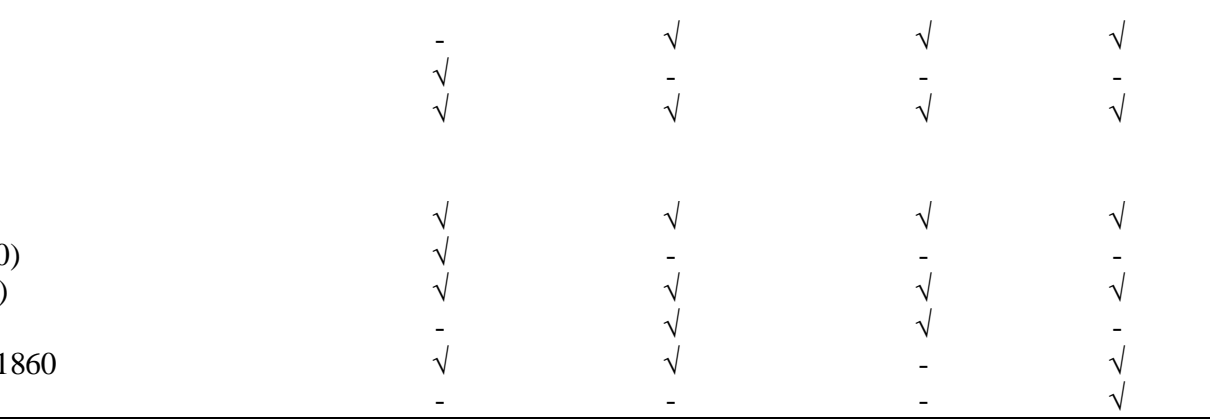

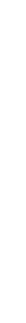

In the rainforests, as many 39 species (20\%) were only found in this land-use system; these are unique species and indeed live in heterogeneous forests. For example, Trogonoptera brookiana and Troides amphrysus are species that are only found in the forest. Both species are protected in Indonesia, based on government regulations on the protection of plants and animals in Indonesia No p20 of 2018 and are classified as "near threatened" by the IUCN Red List (IUCN 2020). The existence of species that can only be found in specific habitats is related to feed availability. The diversity of plants found in heterogeneous forests (Rembold et al. 2017) supports the high diversity of butterflies in that land-use system. Research conducted by Nyafwono et al. (2014) also concluded that some specialist species of butterflies are particularly attracted to heterogeneous forests because they are supported by host plant biomass and imago feed, so these butterflies can be used as indicators of forests. Butterfly species only found in the jungle rubber plantations included which 20 species. The function of land-use systems as a rubber plantation, also has species that are only found in the garden as many as four species. 42 species were found in the four land-uses (Figure 5; Table 1). The same butterfly species found across the four land-uses (42 species) is a species commonly found in settlements and has a wide distribution (D'Abrera 1990).

Differences in diversity and the abundance of butterflies in forests and plantations indicate that they are sensitive to changes in land-use (Gilbert 2012). In fact, butterflies are sensitive to changes in both abiotic environmental conditions (Hantson and Baz 2013; Molina-Martínez et al. 2016) and also plant community composition and other biotic factors (Nyafwono et al. 2014). One factor that makes butterflies as an indicator of environmental quality is that their presence is closely related to the plant species found in ecosystems (Hantson and Baz 2013). The higher the plant diversity found in ecosystems, the higher the corresponding diversity of butterflies (Hantson and Baz 2013), which may be due to the complexity of different land-uses (Hector et al. 2011; Molina-Martínez et al. 2016). Graça et al. (2017) found that the composition of butterflies in forests was different and higher compared to garden habitats in the tropics.

The conclusion from the results of this study is that different land-use results in differences in the wealth and abundance of butterflies. Forests are complex ecosystems and support a high diversity of butterflies compared to gardens. Butterflies are important as pollinators and environmental indicators, and play a role in the food chain, so it is important to maintain their presence in their habitat.

\section{ACKNOWLEDGEMENTS}

RP thanks the Education Fund Management Institute (LPDP) for funding her doctorate studies at Bogor Agricultural University. Part of this research was supported by the Deutsche Forschungs Gemeinschaft (DFG, German Research Foundation)-project number 192626868-SFB 990 in the framework of the collaborative German-Indonesian research project CRC990. We thank the following individuals and organizations for granting us access to and use of their properties: village heads, local plot owners, PT Humusindo, PT REKI and Bukit Duabelas National Park.

\section{REFERENCES}

Alexander LG, DeVries PJ. 2012. Variation in capture height and trap persistence among three Costa Rican understorey butterfly species. J Trop Ecol 28 (6): 585-589. DOI: 10.1017/S02 66467412000533

Azhar B, Lindenmayer DB, Wood J, Fischer J, Manning A, McElhinny C, Zakaria M. 2011. The conservation value of oil palm plantation estates, smallholdings and logged peat swamp forest for birds. For Ecol Manag 262 (12): 2306-2315. DOI: 10.1016/j.foreco.2011.08.026.

Barnes AD, Jochum M, Mumme S, Haneda NF, Farajallah A, Widarto TH, Brose U. 2014. Consequences of tropical land-use for multitrophic biodiversity and ecosystem functioning. Nat Commun 5 (1): 1-7. DOI: 10.1038/ncomms6351.

Brown LM, Crone EE. 2016. Individual variation changes dispersal distance and area requirements of a checkerspot butterfly. Ecology 97 (1): 106-115.

Chahyadi E, Bibas E. 2016. Jenis-jenis kupu-kupu (Sub Ordo Rhopalocera) yang terdapat di kawasan Hapanasan, Kabupaten Rokan Hulu, Provinsi Riau. Jurnal Riau Biologia 1 (1): 50-56. [Indonesian]

D’Abrera. 1990. Butterflies of the Australian Region. Hill House, London. Drescher J, Rembold K, Allen K, Beckschäfer P, Buchori D, Clough Y, Faust H, Fauzi AM, Gunawan D, Hertel D. 2016. Ecological and socio-economic functions across tropical land-use systems after rainforest conversion. Phil Trans R Soc B 371 (1694): 1-8. DOI: 10.1098/rstb.2015.0275.

Estalita RS, Basukriadi A. 2012. Kelimpahan dan keanekaragaman spesies kupu-kupu (Lepidoptera; Rhopalocera) pada berbagai tipe habitat di Hutan Kota Muhammad Sabki Kota Jambi. Biospecies 5 (2): 40-48. [Indonesian] 
Fenner J, Schartel T, Counterman B. 2018. Lessons from Butterflies of the Black Belt Prairie: The Southern Dogface as an Indicator of Prairie Remnants. Trans Am Entomol Soc 144 (2): 295-309. DOI: $10.2307 / 26570154$

Fukano Y, Tanaka Y, Farkhary SI, Kurachi T. 2016. Flower-visiting butterflies avoid predatory stimuli and larger resident butterflies: Testing in a butterfly pavilion. PloS One 11 (11): e0166365. DOI: 10.1371 / journal.pone. 0166365 .

Gilbert N. 2012. Palm-oil boom raises conservation concerns. Nature 487 (7405): 14-15. DOI: 10.1038/487014a.

Graça MB, Souza JL, Franklin E, Morais JW, Pequeno PA. 2017. Sampling effort and common species: optimizing surveys of understorey fruit-feeding butterflies in the Central Amazon. Ecol Indicators 73 (1): 181-188. DOI: 10.1016/j.ecolind. 2016.09.040.

Grass I. 2020. Trade-offs between multifunctionality and profit in tropical smallholder landscapes. Nat Commun 11 (1): 1-13. DOI: 10.1038/s41467-020-15013-5.

Gray RE, Slade EM, Chung AY, Lewis OT. 2019. Movement of moths through riparian reserves within oil palm plantations. J Appl Ecol 2: 1-7. DOI: $10.1111 / 1365-2664.13472$

Hantson S, Baz A. 2013. Seasonal change in nectar preference for a Mediterranean butterfly community. J Lepidop Soc 67 (2): 134-142. DOI: $10.18473 /$ lepi.v67i2.a5.

Harmonis H, Saud OR. 2017. Effects of habitat degradation and fragmentation on butterfly biodiversity in West Kotawaringin, Central Kalimantan, Indonesia. Biodiversitas 18 (2): 500-506. DOI 10.13057/biodiv/d180208.

Hector A, Philipson C, Saner P, Chamagne J, Dzulkifli D, O'Brien M, Snaddon JL, Ulok P, Weilenmann M, Reynolds G. 2011. The Sabah Biodiversity Experiment: a long-term test of the role of tree diversity in restoring tropical forest structure and functioning. Philos Trans $\mathrm{R}$ Soc B: Biol Sci 366 (1582): 3303-3315. DOI: 10.1098/rstb.2011.0094.

Hothorn T, Everitt BS. 2009. A Handbook of Statistical Analyses using R. Chapman and Hall/CRC, London.

IUCN [International Union for Conservation of Nature's]. 2020. IUCN Red List of Species. https://www.iucnredlist.org/ search?query=trogonoptera\&searchType $=$ species

Koneri R, Maabuat PV. 2016. Diversity of Butterflies (Lepidoptera) in Manembo-Nembo Wildlife Reserve, North Sulawesi, Indonesia. Pak J Biol Sci 19 (5): 202. DOI: 10.3923/pjbs.2016.202.210.

Kumar A. 2013. Butterfly (Lepidoptera: Insecta) diversity from different sites of Jhagadia, Ankleshwar, district-Bharuch, Gujarat. Octa J Environ Res 1 (1): 9-18.

Meijide A, Badu CS, Moyano F, Tiralla N, Gunawan D, Knohl A. 2018. Impact of forest conversion to oil palm and rubber plantations on microclimate and the role of the 2015 ENSO event. Agric For Meteorol 252: 208-219. DOI: 10.1016/j.agrformet.2018.01.013.

Molina-Martínez A, León-Cortés JL, Regan HM, Lewis OT, Navarrete D, Caballero U, Luis-Martínez A. 2016. Changes in butterfly distributions and species assemblages on a Neotropical mountain range in response to global warming and anthropogenic land-use. Divers Distrib 22 (11): 1085-1098. DOI: 10.111 1/ddi. 12473

Morris EK, Caruso T, Buscot F, Fischer M, Hancock C, Maier TS, Meiners T, Müller C, Obermaier E, Prati D. 2014. Choosing and using diversity indices: insights for ecological applications from the German Biodiversity Exploratories. Ecol Evol 4 (18): 3514-3524. DOI: 10.1002/ece3.1155.

Mukherjee S, Banerjee S, Basu P, Saha G, Aditya G. 2015. Lantana camara and butterfly abundance in an urban landscape: Benefits for conservation or species invasion? Ekológia (Bratislava). 34 (4): 309 328. DOI: 10.1515/eko-2015-0029

Nidup T, Dorji T, Tshering U. 2014. Taxon diversity of butterflies in different habitat types in Royal Manas National Park. Entomol Zoo Stud J 2 (6): 292-298. DOI: 301887084

Nyafwono M, Valtonen A, Nyeko P, Roininen H. 2014. Fruit-feeding butterfly communities as indicators of forest restoration in an Afrotropical rainforest. Biol Conserv 174: 75-83. DOI: 10.1016/j.biocon.2014.03.022.

Peggie D. 2014. Diversitas dan pentingnya kupu-kupu Nusa Kambangan, Jawa, Indonesia. Zoo Indonesia 23 (1): 45-55. [Indonesian]

Rembold K, Mangopo H, Tjitrosoedirdjo SS, Kreft H. 2017. Plant diversity, forest dependency, and alien plant invasions in tropical agricultural landscapes. Biol Conserv 213: 234-242. DOI: 10.1016/j.biocon.2017.07.020.

Rusman R. 2015. Kupu-Kupu (Lepidoptera: Papilionoidea) di Gunung Sago, Sumatera Barat: Keanekaragaman dan Preferensi Kunjungan pada Bunga. [Thesis]. Institut Pertanian Bogor, Bogor, Indonesia. [Indonesian]

Seki Y, Takanami Y, Otsuka K. 1991. Butterflies of Borneo 2 (1) Lycaenidae. Tobishima Corporation, Japan.

Sodhi NS, Posa MRC, Lee TM, Bickford D, Koh LP, Brook BW. 2010. The state and conservation of Southeast Asian biodiversity. Biodivers Conserv J 19 (2): 317-328. DOI: 10.1007/s10531-009-9607-5.

Teuscher M, Gérard A, Brose U, Buchori D, Clough Y, Ehbrecht M, Hölscher D, Irawan B, Sundawati L, Wollni M. 2016. Experimental biodiversity enrichment in oil-palm-dominated landscapes in Indonesia. Front Plant Sci 7: 1-15. DOI: 10.3389/fpls.2016.01538.

Wheeler D, Hammer D, Kraft R, Dasgupta S, Blankespoor B. 2013. Economic dynamics and forest clearing: A spatial econometric analysis for Indonesia. Ecol Econ 85: 85-96. DOI: 10.1016/ j.ecolecon.2012.11.005 